\title{
MIR211 wt Allele
}

National Cancer Institute

\section{Source}

National Cancer Institute. MIR211 wt Allele. NCI Thesaurus. Code C98177.

Human MIR211 wild-type allele is located in the vicinity of $15 q 13.3$ and is approximately $110 \mathrm{bp}$ in length. This allele, which encodes MIR211 pre-miRNA, plays a role in gene regulation. 